\title{
The Effects of Verbal and Non-Verbal Features on the Reception of DRTV Commercials
}

\begin{abstract}
Analyses of consumer response are important for successful advertising as they help advertisers to find new, original and successful ways of persuasion. Successful advertisements have to boost the product's benefits but they also have to appeal to consumers' emotions. In TV advertisements, this is done by means of verbal and non-verbal strategies. The paper presents the results of an empirical investigation whose purpose was to examine the viewers' emotional responses to a DRTV commercial induced by different verbal and non-verbal features, the amount of credibility and persuasiveness of the commercial and its general acceptability. Our findings indicate that (1) an overload of the same verbal and non-verbal information decreases persuasion; and (2) highly marked prosodic delivery is either exaggerated or funny, while the speaker is perceived as annoying.
\end{abstract}

Keywords: persuasive communication; prosody; English language; direct response television (DRTV) short form spots

\section{Učinki verbalnih in neverbalnih lastnosti na sprejem kratkih TV oglasnih sporočil $\mathrm{z}$ neposrednim odzivom}

\section{POVZETEK}

Analize odziva potrošnikov so pomembne za uspešno oglaševanje, saj oglaševalcem pomagajo poiskati nove, izvirne in uspešne načine prepričevanja. Uspešni oglasi morajo poudarjati koristi oglaševanega izdelka, hkrati pa morajo tudi vplivati na potrošnikova čustva. $\mathrm{V}$ televizijskem oglaševanju se to doseže s pomočjo verbalnih in neverbalnih postopkov. $\mathrm{V}$ tem članku so predstavljeni rezultati testiranja, katerega namen je bil ugotoviti gledalčeve čustvene odzive na televizijsko oglasno sporočilo z neposrednim odzivom, ki so jih sprožile tako verbalne kot neverbalne lastnosti. Preverjali smo tudi, ali je oglasno sporočilo za gledalce vredno zaupanja, prepričljivo in splošno sprejemljivo. Naše ugotovitve kažejo na to, da (1) prenatrpanost z enakimi verbalnimi in neverbalnimi informacijami zmanjšuje prepričljivost; in (2) da raba zelo zaznamovane stavčne intonacije učinkuje bodisi kot pretiravanje ali smešno, govorec pa zveni nadležno.

Ključne besede: prepričevalno sporazumevanje; prozodija; angleški jezik; kratki oglasi z neposrednim odzivom 


\section{The Effects of Verbal and Non-Verbal Features on the Reception of DRTV Commercials}

\section{Introduction}

The guiding principles in advertising are to capture consumers' attention, create interest in the advertised product, convince the consumers to desire the product and persuade them to buy it. In order to meet these four basic principles of the so-called AIDA model, ${ }^{1}$ advertisers employ different persuasive strategies which include verbal and non-verbal elements.

One form of advertising is TV commercials. They are often regarded as a nuisance which viewers accept with varying degrees of tolerance. ${ }^{2}$ A variety of TV advertisements are the so-called direct response television (DRTV) commercials which fall into two categories: infomercials (up to 60 minutes long) and short form spots (from 60 to 120 seconds long). Both types of commercials are also known as TV commercials for online shopping or shopping from the armchair. DRTV commercials are broadcast either on special shopping TV channels or are part of shopping programmes on regular TV channels. Due to their brevity, DRTV short form spots often occur in commercial slots which interrupt regular TV programmes, such as films (see HawthornDirect n.d.).

Our structural and linguistic analysis of three English DRTV short form spots (Komar 2015) found that their creators (1) used verbal and non-verbal communication strategies to meet the requirements of the AIDA model; (2) exhibited lexically and syntactically less complex language which does not require much cognitive effort on the part of the viewers; (3) intensified the spoken delivery through highly marked intonation. We discovered that DRTV short form spots used the same verbal and non-verbal patterns of persuasive communication but we could not claim that these patterns were also convincing and made the viewers buy the advertised products. In order to find out what effects the verbal and non-verbal persuasive techniques may have on viewers and potential buyers, we decided to test the response to one English DRTV short form spot with a group of students of English at the Faculty of Arts, University of Ljubljana whose expected level is C1 in terms of CEFR (Common European Framework of Reference for Languages) descriptors for listening comprehension (Council of Europe 2001). ${ }^{3}$

The paper is structured as follows. In Section 2, we present an overview of relevant research in the field of persuasive communication, the influence of emotions on the reception of advertisements, and the main findings of our linguistic and structural analysis of three DRTV short form spots. In Section 3, we describe the method, the participants and the results of our empirical investigation of consumer response to the Eggies DRTV short form spot. Section 4 is dedicated to the discussion of the findings and Section 5 presents the main conclusions and suggests further studies.

\footnotetext{
AIDA is an acronym for Attention, Interest, Desire, and Action. The authorship of the AIDA model is attributed to E. St. Elmo Lewis, the late-19 $9^{\text {th }}$-century American advertising pioneer (see Communication Theory n.d.).

An opinion poll carried out in 2005 among the students of two major Slovene universities showed that $75 \%$ of participants were annoyed by TV advertisements, while $70 \%$ were bored by watching the same commercials (Andrejc 2005).

Eggies, plastic dishes for cooking hard or soft boiled eggs.
} 


\section{Theoretical Overview, Linguistic and Non-Linguistic Features of DRTV Short Form Spots, and Research Questions}

\subsection{Theoretical Overview}

The guiding principle of advertising is to persuade the consumers to desire and buy the advertised product. This is achieved by changing the consumers' beliefs and attitudes towards the product, and one of the most successful strategies for achieving this goal is to appeal to the addressees' emotions. According to the cognitive Elaboration Likelihood Model (ELM) developed by Petty and Cacioppo (1986), information is processed via two routes: the central and the peripheral. The former requires careful and thoughtful processing of information, whereas the latter involves positive associations and emotions. Information received via the peripheral route is the result of the positive or negative appeal of the message and not the logical processing of the message. Petty and Briñol (2015) recognise a finite set of ways in which emotions influence attitudes in the elaboration continuum. They claim that the amount of thinking invested during the influence period moderates the effect of emotions on attitudes. When people are not engaged in careful thinking (low thinking), emotions influence attitudes by minimal effort via the peripheral route. In addition, emotions affect attitudes in agreement with their valence: pleasant emotions generate positive attitudes, while unpleasant emotions generate negative attitudes. On the other hand, when people are motivated to think (high thinking), the influence of emotions on the attitudes changes: it is no longer the valence of emotions that counts, but rather their relevance in the given context. In other words, people take time and carefully evaluate the emotional impact on the attitudes and judgements.

Which of the two routes for processing information will be used depends on such subjective and contextual factors as the recipient's personal characteristics, the mood during the exposure to the information, ${ }^{4}$ the informativity of the message and its relevance for the recipient's life, and an array of possible noises in communication - from physical (e.g. loud music, traffic, ringing of a phone) to linguistic (e.g. different languages or dialects, difficult vocabulary and syntax, repetition of identical structures), semantic (e.g. different understanding of a particular lexical item), and psychological noises (e.g. prejudices, narrow-mindedness). But the bottom line principle is that personally relevant information will induce interest and careful thinking in the recipient, who will in turn process information via the central route of persuasion. If the recipient does not find the information personally relevant, its processing will be superficial and carried out via the peripheral route of persuasion.

In advertising a strong emotional appeal, which can be either positive (e.g. humour, happiness, friendship, enthusiasm) or negative (e.g. fear, sadness, discomfort), is often used to meet the first criterion of the AIDA model, which is to capture the consumers' attention. In other words, advertisers try to reach out to consumers via the peripheral route of persuasion. However, if they want to create and retain the consumers' interest and persuade them to buy, they have to appeal to them also via the central route of persuasion. Mai and Schoeller (2009) found that the

Puccinelli, Wilcox and Grewal (2015) found that viewers who were in a negative emotional state (e.g. sadness) induced by the TV programme they watched, found highly energetic and positive TV advertisements difficult to watch compared to viewers who were in a neutral or positive emotional state. 
most memorable and convincing advertisements were those which triggered positive emotions in consumers, whereas advertisements in which factual and logic-rich information prevailed were less memorable.

A similar conclusion was reached by Adler et al. (2015) who studied emotional and rational persuasion strategies in computer-mediated dialogues whose purpose was to persuade participants to learn more about Tai Chi and its benefits for health. They used four persuasive strategies (emotional positive, rational positive, emotional negative and rational negative) and compared the results. ${ }^{5}$ They found that an emotional positive strategy of persuasion was more effective than a rational positive strategy, while emotional negative and rational negative strategies produced negative results. They suggested that " $\mathrm{t}]$ he continuous use of an Emotional Positive strategy when persuading users may be the most effective choice" (Adler et al. 2015, 80).

There are a number of different studies which examined the influence of linguistic and nonlinguistic features on persuasion. Within the framework of ELM, Nikolaus, Roessing and Petersen (2011) studied the effects of verbal and non-verbal elements in persuasive communication and found that verbal elements played a more important role in the central route of persuasion, whereas in the peripheral route of persuasion people rely more on non-verbal elements, such as body language.

Several studies which examined the relationship between language and social power (Lakoff 1975; O'Barr 1982; Sparks and Areni 2002; Areni and Sparks 2005) found a positive correlation between the two: speakers with high social power use powerful language, whereas speakers with low social power tend to use powerless language. Powerful language triggers more favourable attitudes and is more persuasive.

Linguistic intensity or extremity is one of the characteristics of powerful language. Studies by Cacioppo (1986) and Craig and Blankenship (2011) found that the use of linguistic intensity markers (e.g. adjectives, adverbs, verbs, different discourse or pragmatic markers) increased persuasion and credibility. Averbeck and Miller (2014) found a close relationship between syntactic forms of linguistic intensity or extremity and cognitive complexity: individuals with a better ability to think in abstract terms would prefer a syntactically complex message, which they would find more persuasive, as opposed to individuals with a better ability to think in concrete terms, who would prefer syntactically simple messages.

In television advertisements, spoken delivery, sound effects and visual images also play an important role in the reception, credibility and persuasiveness of the advertisement. Chattopadhyay et al. (2003) found that fast speech at a lower pitch was not only more attractive but also more convincing, truthful and persuasive. Elbert and Dijkstra (2014), in their study of the relationship between voice intonation and persuasion, came to the conclusion that a high level of intonation can decrease persuasion. They explained this by suggesting that intonation increased the density of information; such an information overload decreased rather than increased persuasion.

Emotional Positive strategy uses statements which appeal to positive emotions. Rational Positive strategy contains positive statements with logical or scientific arguments. Emotional Negative strategy focuses on negative consequences. Rational Negative strategy contains negative logical arguments (for examples, see Adler et al. 2015, 79). 


\subsection{Linguistic and Non-Linguistic Features of DRTV Short Form Spots}

This section sums up the main linguistic and non-linguistic features of three DRTV short form spots (Komar 2015); we discerned that these broadcast advertisements exhibited similar patterns of verbal and non-verbal persuasive communication. What remained to be investigated was whether these patterns really convinced viewers and made them purchase the products. Our findings also served as the basis for setting up the questionnaires with which we tested the consumers' response to the DRTV short form spots.

As presented in the 2015 study, the structural analysis of three DRTV short form spots showed that they had many verbal and non-verbal features in common. As far as their visual and auditory delivery and structure are concerned, they are of similar length in terms of time, number of sentences and words; the products' names are repeated at equal intervals; they all present the problems in black and white technique, while the solutions are filmed in bright colours; the narrator and the actors are verbally (intonation) and non-verbally (facial expressions and body language) very excited; and the problem-solution pattern appears twice in spite of the shortness of the commercial (60-120 seconds). The main points of the auditory and visual information are supported by captions written across the screen (see Appendix 1). The viewers receive an overload of the same information and are expected to execute three different cognitive processes at the same time: listening, watching and reading.

In the same study we also analysed the linguistic features used in the DRTV short form spots to meet the AIDA model and found that the consumers' attention was captured by means of exclamations and question-answer sequences; the interest for the advertised products was retained by the use of statements which provided the solution to the problem; convincing the viewers and persuading them to desire the advertised product was developed by listing its qualities using statements, imperatives and exclamations; the default syntactic structure to meet the last criterion of the AIDA model (i.e. action) was the imperative.

As far as the lexical and syntactic complexity of the DRTV short form spots is concerned, our study found that they contained short sentences and lexical items which made the processing of information easy even though these were informationally condensed texts. ${ }^{6}$

In our 2015 study we also analysed the prosodic features of the DRTV short form spots and found that they used highly marked intonation. The delivery of the text contained many short intonation phrases within one clause which contained two pitch prominent syllables - the nuclear and the pre-nuclear one. The texts contained many repetitions of the same words, phrases or clauses which were regularly delivered with the nucleus on the same item, thus violating the basic principle of tonicity, namely, that the nucleus should occur on new information. The prevailing pitch movements consisted of either a high falling tone or a high pre-nuclear segment and a high falling tone which indicated a high degree of involvement and enthusiasm expressed by the speaker over the advertised products.

According to Flesch Reading Ease and Flesch-Kincade Grade Level the DRTV short form spots are easily understood by children between the ages of 8 and 13 (Komar 2015, 45).

For a detailed analysis of intonation in DRTV short form spots, see Komar $(2015,40-44)$. 


\subsection{Research Questions}

On the basis of the above theoretical assumptions and the results of our structural and linguistic analysis of DRTV short form spots, we decided to test the viewers' response to this type of TV commercials in order to answer the following research questions:

RQ1 How does repetition of identical lexical items, syntactic structures and the product's name influence credibility and persuasion?

RQ2 How does a highly marked audio-visual delivery increase interest and influence credibility?

RQ3 What influence does spoken delivery (speaker's voice, pitch, speed and volume) have on the viewers' emotional response to DRTV short form spots?

\section{The Study}

\subsection{Participants and Method}

In October 2015 we invited 96 first-year students of English (22 male and 74 female) to participate in an experiment to test the effects of DRTV short form spots on the behaviour of potential consumers of Eggies (plastic dishes for cooking hard and soft-boiled eggs without a shell). The empirical investigation was carried out during a course on English Phonetics and Phonology as an introduction to the topic of English prosody. The purpose of the empirical investigation was explained to the participants, and they were instructed to provide honest and sincere answers to the questions. The results of the empirical investigation were later discussed with the students and served as a good example on the importance of spoken delivery, particular intonation, for the reception of information.

Before the exposure to the Eggies DRTV short form spot, the participants had to answer a previewing questionnaire about their experiences with cooking hard-boiled eggs and their interest in acquiring a tool for an easier way of cooking hard-boiled eggs (see Appendix 2). In this way we tested how relevant and informative a commercial like Eggies could be for the viewers.

Having watched the Eggies DRTV short form spot, the participants proceeded to the second questionnaire, in which they had to answer questions concerning the informativity and persuasiveness of the DRTV short form spot. Additionally, they had to evaluate their emotional reactions to the commercial, as well as the delivery and the voice of the presenter (see Appendix 3).

\subsection{Results}

\subsubsection{Pre-Viewing Questionnaire}

Table 1 shows the results of the pre-viewing questionnaire, whose purpose was to find the participants' experiences with cooking hard-boiled eggs. We can observe that the majority of them (97.9\%) know how to cook a hard-boiled egg and do not find it to be a difficult culinary undertaking. When it comes to peeling a hard-boiled egg, the answers are more varied: more than a half of the participants (56.3\%) find the task messy, whereas $40.6 \%$ find it easy. Although $68.7 \%$ of participants think that cooking and peeling a hard-boiled egg can be made easier, $54.1 \%$ of them would not buy a tool which could make the tasks easier, whereas $41.7 \%$ might 
decide to purchase such a product. There were more male participants than female who would not buy such a tool.

These results suggest that the Eggies DRTV short form spot will be of interest for more than two thirds of the participants $(68.7 \%)$. On the other hand, the commercial has to be very convincing to persuade the $54.1 \%$ of the participants who do not consider buying a product like Eggies at all.

TABLE 1. Results of the pre-viewing questionnaire.

\begin{tabular}{|c|c|c|c|}
\hline \multicolumn{4}{|c|}{ Q1: Do you know how to cook a hard-boiled egg? } \\
\hline & \multicolumn{2}{|l|}{ YES } & NO \\
\hline All participants $(n=96 ; 100 \%)$ & \multicolumn{2}{|c|}{$94(97.9 \%)$} & $2(2.1 \%)$ \\
\hline Female $(\mathrm{n}=74 ; 77 \%)$ & \multicolumn{2}{|c|}{$73(76 \%)$} & $1(1 \%)$ \\
\hline Male $(\mathrm{n}=22 ; 23 \%)$ & \multicolumn{2}{|c|}{$21(22 \%)$} & $1(1 \%)$ \\
\hline Female $(n=74 ; 100 \%)$ & \multicolumn{2}{|c|}{$73(98.6 \%)$} & $1(1.4 \%)$ \\
\hline Male $(\mathrm{n}=22 ; 100 \%)$ & \multicolumn{2}{|c|}{$21(96.5 \%)$} & $1(4.5 \%)$ \\
\hline \multicolumn{4}{|c|}{ Q2: Do you find cooking hard-boiled eggs difficult? } \\
\hline & \multicolumn{2}{|l|}{ YES } & NO \\
\hline All participants $(n=96 ; 100 \%)$ & \multicolumn{2}{|l|}{$2(2.1 \%)$} & $94(97.9 \%)$ \\
\hline Female $(\mathrm{n}=74 ; 77 \%)$ & \multicolumn{2}{|l|}{0} & $74(77.1 \%)$ \\
\hline Male $(n=22 ; 23 \%)$ & $2(2.1 \%)$ & & $20(20.8 \%)$ \\
\hline Female $(n=74 ; 100 \%)$ & 0 & & $74(100 \%)$ \\
\hline Male $(n=22 ; 100 \%)$ & $2(9.1 \%)$ & \multicolumn{2}{|c|}{$20(90.9 \%)$} \\
\hline \multicolumn{4}{|c|}{ Q3: How do you find peeling a hard-boiled egg? } \\
\hline & EASY & DIFFICULT & MESSY \\
\hline All participants $(n=96 ; 100 \%)$ & $39(40.6 \%)$ & $3(3.1 \%)$ & $54(56.3 \%)$ \\
\hline Female $(\mathrm{n}=74 ; 77 \%)$ & $30(31.3 \%)$ & 0 & $44(45.8 \%)$ \\
\hline Male $(\mathrm{n}=22 ; 23 \%)$ & $9(9.4 \%)$ & $3(3.1 \%)$ & $10(10.4 \%)$ \\
\hline Female $(n=74 ; 100 \%)$ & $30(40.5 \%)$ & 0 & $44(59.5 \%)$ \\
\hline Male $(n=22 ; 100 \%)$ & $9(40.9 \%)$ & $3(13.6 \%)$ & $10(45.5 \%)$ \\
\hline Q4: Do you think that cookin & ng hard-boiled & could be made & sier? \\
\hline & YES & & NO \\
\hline All participants $(n=96 ; 100 \%)$ & $66(68.7 \%$ & & $31.3 \%)$ \\
\hline Female $(\mathrm{n}=74 ; 77 \%)$ & $51(53.1 \%$ & & $(24 \%)$ \\
\hline Male $(n=22 ; 23 \%)$ & $15(15.6 \%$ & & $7.3 \%)$ \\
\hline Female $(n=74 ; 100 \%)$ & $51(68.9 \%$ & & $31.1 \%)$ \\
\hline Male $(n=22 ; 100 \%)$ & $15(68.2 \%$ & & $31.8 \%)$ \\
\hline $\begin{array}{l}\text { Q5: Would you be interested } \\
\text { hard-boiled eggs easier? }\end{array}$ & product which & uld make cool & and peeling \\
\hline & YES & NO & PERHAPS \\
\hline All participants $(\mathrm{n}=96 ; 100 \%)$ & $4(4.2 \%)$ & $52(54.1 \%)$ & $40(41.7 \%)$ \\
\hline Female $(\mathrm{n}=74 ; 77 \%)$ & $2(2.1 \%)$ & $37(38.5 \%)$ & $35(36.5 \%)$ \\
\hline Male $(\mathrm{n}=22 ; 23 \%)$ & $2(2.1 \%)$ & $15(15.6 \%)$ & $5(5.2 \%)$ \\
\hline Female $(n=74 ; 100 \%)$ & $2(2.7 \%)$ & $37(50 \%)$ & $35(47.3 \%)$ \\
\hline Male $(\mathrm{n}=22 ; 100 \%)$ & $2(9.1 \%)$ & $15(68.2 \%)$ & $5(22.7 \%)$ \\
\hline
\end{tabular}




\subsubsection{Post-Viewing Questionnaire}

After watching the Eggies DRTV short form spot, the participants were given the second questionnaire, in which there were nine questions. The first three questions were about the informativity, and persuasiveness of the DRTV short form spot. The participants had to choose among three offered answers. The following three questions were open and the participants were invited to provide up to five adjectives describing their emotional reactions to the DRTV short form spots, and five features which made the commercial appealing as well as unattractive. Questions 7 and 8 concerned the delivery and the voice of the narrator. The participants were offered five adjectives in each question and their task was to choose one or more than one label. In the last question the participants had to decide whether the gender of the narrator was appropriate for the Eggies DRTV short form spot.

\subsubsection{Informativity and Persuasiveness of the Eggies DRTV Short Form Spot}

Table 2 shows the results for the first three questions in the post-viewing questionnaire. We can conclude that more than a half of all participants (52\%) found the commercial adequately informative, whereas approximately one third of them (31.3\%) found it very informative. The male participants found the commercial very informative, in a higher percentage (36.4\%), than the female participants $(29.7 \%)$.

The commercial is convincing for $78 \%$ of all participants, with a higher percentage of female (82.4\%) than male (63.6\%) participants. However, a large majority of all participants (82.3\%), regardless of the gender, answered that they would not buy Eggies.

TABLE 2. Informativity and persuasiveness of the Eggies DRTV short form spot: results of the post-viewing questionnaire.

\begin{tabular}{|c|c|c|c|}
\hline \multicolumn{4}{|c|}{ Q1: How informative was the commercial? } \\
\hline & VERY & JUST ENOUGH & NOT ENOUGH \\
\hline All participants $(n=96 ; 100 \%)$ & $30(31.3 \%)$ & $50(52 \%)$ & $16(16.7 \%)$ \\
\hline Female $(n=74 ; 77 \%)$ & $22(22.9 \%)$ & $41(42.7 \%)$ & $11(11.5 \%)$ \\
\hline Male $(\mathrm{n}=22 ; 23 \%)$ & $8(8.3 \%)$ & $9(9.4 \%)$ & $5(5.2 \%)$ \\
\hline Female $(n=74 ; 100 \%)$ & $22(29.7 \%)$ & $41(55.4 \%)$ & $11(14.9 \%)$ \\
\hline Male $(\mathrm{n}=22 ; 100 \%)$ & $8(36.4 \%)$ & $9(40.9 \%)$ & $5(22.7 \%)$ \\
\hline \multicolumn{4}{|c|}{$\begin{array}{l}\text { Q2: Did the commercial convince you that there was an easier way of cooking and peeling } \\
\text { hard-boiled eggs? }\end{array}$} \\
\hline & & \begin{tabular}{|l|l} 
YES & \\
\end{tabular} & NO \\
\hline \multicolumn{2}{|l|}{ All participants $(n=96 ; 100 \%)$} & $75(78 \%)$ & $21(22 \%)$ \\
\hline \multicolumn{2}{|l|}{ Female $(\mathrm{n}=74 ; 77 \%)$} & $61(63.5 \%)$ & $13(13.6 \%)$ \\
\hline \multicolumn{2}{|l|}{ Male $(n=22 ; 23 \%)$} & $14(14.6 \%)$ & $8(8.3 \%)$ \\
\hline \multicolumn{2}{|l|}{ Female $(n=74 ; 100 \%)$} & $61(82.4 \%)$ & $13(17.6 \%)$ \\
\hline \multicolumn{2}{|c|}{\begin{tabular}{|l|l} 
Male $(\mathrm{n}=22 ; 100 \%)$ & \\
\end{tabular}} & $14(63.6 \%)$ & $8(36.4 \%)$ \\
\hline \multicolumn{4}{|c|}{ Q3: Were you persuaded to buy the product? } \\
\hline \multicolumn{2}{|c|}{ 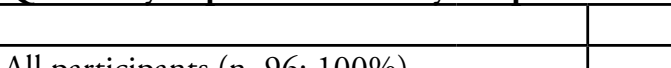 } & YES & NO \\
\hline \multicolumn{2}{|c|}{\begin{tabular}{l|l} 
All participants $(\mathrm{n}=96 ; 100 \%)$ & \\
\end{tabular}} & $17(17.7 \%)$ & $79(82.3 \%)$ \\
\hline \multicolumn{2}{|l|}{ Female $(\mathrm{n}=74 ; 77 \%)$} & $14(14.6 \%)$ & $60(62.5 \%)$ \\
\hline \multicolumn{2}{|l|}{ Male $(n=22 ; 23 \%)$} & $3(3.1 \%)$ & $19(19.8 \%)$ \\
\hline \multirow{2}{*}{\multicolumn{2}{|c|}{$\begin{array}{l}\text { Female }(n=74 ; 100 \%) \\
\text { Male }(n=22 ; 100 \%)\end{array}$}} & $14(18.9 \%)$ & $60(81.1 \%)$ \\
\hline & & $3(13.6 \%)$ & $19(86.4 \%)$ \\
\hline
\end{tabular}




\subsubsection{Emotional Reactions to the Eggies DRTV Short Form Spot}

The fourth question was an open one and required the participants to provide up to five adjectives describing their emotional reactions to the Eggies DRTV short form spot. Table 3 presents the number of adjectives chosen by the participants. The participants described their emotional reactions to the commercial mostly with two or three adjectives, twenty of them chose four or five adjectives.

TABLE 3. Number of adjectives chosen by the participants.

\begin{tabular}{|l|c|c|c|c|c|}
\hline & 1 adjective & 2 adjectives & 3 adjectives & 4 adjectives & 5 adjectives \\
\hline $\begin{array}{l}\text { Participants } \\
(\mathrm{n}=96 ; 100 \%)\end{array}$ & $19(19.8 \%)$ & $30(31.3 \%)$ & $27(28.1 \%)$ & $10(10.4 \%)$ & $10(10.4 \%)$ \\
\hline
\end{tabular}

The participants listed 26 different adjectives; these are presented in Table 4 together with their number of occurrences. It is evident that among the most frequently mentioned adjectives are those which express positive emotions (amused, happy, excited, entertained), whereas adjectives expressing negative emotional states (bored, sceptical, stupid, silly, ridiculous) were much less frequent.

TABle 4. Adjectives Used to Describe Emotional Reactions to Eggies DRTV Short Form Spots.

\begin{tabular}{|l|c|l|c|l|c|l|l|l|c|}
\hline Adjective & $\mathbf{N}$ & Adjective & $\mathbf{N}$ & Adjective & $\mathbf{N}$ & Adjective & $\mathbf{N}$ & Adjective & $\mathbf{N}$ \\
\hline amused & 33 & confused & 17 & nice & 8 & sceptical & 4 & ridiculous & 3 \\
\hline happy & 29 & surprised & 17 & hungry & 6 & impressed & 3 & disappointed & 2 \\
\hline interested & 21 & annoyed & 15 & amazed & 4 & silly & 3 & puzzled & 1 \\
\hline excited & 18 & entertained & 8 & bored & 4 & stupid & 3 & unconvinced & 1 \\
\hline
\end{tabular}

\subsubsection{Factors Influencing the Appeal of the Commercial}

The fifth and the sixth questions specifically asked the participants to provide up to five features that made the commercial attractive (question 5) or unattractive (question 6). Table 5 presents the number of features chosen by the participants and their frequencies of occurrence in response to question 5. We can see that the majority of participants chose up to three features which made the commercial appealing.

TABLE 5. Number of features chosen by the participants.

\begin{tabular}{|l|c|c|c|c|c|}
\hline & 1 feature & 2 features & 3 features & 4 features & 5 features \\
\hline $\begin{array}{l}\text { Participants } \\
\text { (n=96; 100\%) }\end{array}$ & $23(24 \%)$ & $36(37.5 \%)$ & $27(28.1 \%)$ & $6(6.2 \%)$ & $4(4.2 \%)$ \\
\hline
\end{tabular}

The participants chose 12 features which contributed to the attractiveness of the Eggies DRTV short form spot. They are presented in Table 6 .

TABLE 6. Factors which made the commercial appealing.

\begin{tabular}{|l|c|l|c|l|c|}
\hline Feature & N & Feature & N & Feature & N \\
\hline music & 28 & product's name & 6 & excitement & 3 \\
\hline colours & 27 & happiness & 5 & vivid pictures & 2 \\
\hline food & 26 & innovation & 5 & simple language & 2 \\
\hline nice voice & 15 & cooking & 5 & simplicity & 1 \\
\hline
\end{tabular}


The sixth question required the participants to list up to five features which made the commercial unattractive. Table 7 shows that the participants mainly chose one or two features to describe the unattractiveness of the Eggies DRTV short form spot.

TABLE 7. Number of features chosen by the participants.

\begin{tabular}{|l|c|c|c|c|c|}
\hline & 1 feature & 2 features & 3 features & 4 features & 5 features \\
\hline $\begin{array}{l}\text { Participants } \\
(\mathrm{n}=96 ; 100 \%)\end{array}$ & $40(41.7 \%)$ & $34(35.4 \%)$ & $16(16.7 \%)$ & $3(3.1 \%)$ & $3(3.1 \%)$ \\
\hline
\end{tabular}

The participants exhibited less variation in their answers than in the previous question. Table 8 presents six features and their frequency of occurrence in the participants' responses. We can observe that non-verbal elements, such as the voice of the speaker and the delivery, were among the most frequently mentioned factors contributing to the unattractiveness of the commercial.

TABLE 8. Factors which made the commercial unattractive.

\begin{tabular}{|l|l|l|l|l|l|}
\hline Feature & $\mathbf{N}$ & Feature & N & Feature & N \\
\hline $\begin{array}{l}\text { voice (annoying, } \\
\text { squeaky, high-pitched) }\end{array}$ & 49 & $\begin{array}{l}\text { exaggerated } \\
\text { and too excited } \\
\text { delivery }\end{array}$ & 13 & $\begin{array}{l}\text { simple, basic } \\
\text { language }\end{array}$ & 10 \\
\hline $\begin{array}{l}\text { repetition of the } \\
\text { same words, phrases, } \\
\text { product's name }\end{array}$ & 24 & fast delivery & 11 & loud speech & 5 \\
\hline
\end{tabular}

\subsubsection{Delivery, Voice and the Narrator}

The last three questions in the post-viewing questionnaire concerned the delivery, the voice and the gender of the narrator. In question 7, the participants were offered five labels (boring, exaggerated, excited, lively and pleasant) to describe the delivery of the commercial. ${ }^{8}$ They could choose more than one label. Table 9 presents all the choices of the participants. We can observe that the most frequently chosen label is exaggerated, either alone or in combination with excited and lively.

TABLE 9. Delivery of the Eggies DRTV short form spot.

\begin{tabular}{|l|l|l|l|l|l|}
\hline 1 label & $\mathrm{N}=47(49 \%)$ & 2 labels & $\mathrm{N}=37(38.5 \%)$ & 3 labels & $\mathrm{N}=12(12.5 \%)$ \\
\hline Boring & $1(1 \%)$ & $\begin{array}{l}\text { excited/ } \\
\text { exaggerated }\end{array}$ & $8(8.3 \%)$ & $\begin{array}{l}\text { exaggerated/ } \\
\text { excited/lively }\end{array}$ & $10(10.4 \%)$ \\
\hline Exaggerate & $31(32.3 \%)$ & $\begin{array}{l}\text { lively/ } \\
\text { exaggerated }\end{array}$ & $15(15.6 \%)$ & $\begin{array}{l}\text { exaggerated/ } \\
\text { lively/pleasant }\end{array}$ & $2(2.1 \%)$ \\
\hline excited & $6(6.3 \%)$ & lively/excited & $11(11.5 \%)$ & & \\
\hline lively & $6(6.3 \%)$ & lively/pleasant & $3(3.1 \%)$ & & \\
\hline pleasant & $3(3.1 \%)$ & & & & \\
\hline
\end{tabular}

In question 8 the participants were offered five labels (annoying, attractive, pleasant, positive and repulsive) to describe the voice of the narrator. ${ }^{9}$ Here as well they could choose more than

\footnotetext{
8 The choice of labels was made on the basis of the findings of structural and linguistic analyses in our previous study (Komar 2015).

9 The choice of labels was made on the basis of the findings of the prosodic analysis in our previous study (Komar 2015) and theoretical assumptions of Chattopadhyay et al. (2003) and Elbert and Dijkstra (2014).
} 
one label. Table 10 presents the participants' choices. We can observe that the majority of the participants found the narrator's voice either annoying or positive, or even both.

The results for questions 7 and 8 are in agreement with the results for questions 5 and 6 .

TABLE 10. The voice quality of the narrator.

\begin{tabular}{|c|c|c|c|c|c|}
\hline 1 label & $\begin{array}{c}\mathrm{N}=70 \\
(72.9 \%)\end{array}$ & 2 labels & $\begin{array}{c}\mathrm{N}=20 \\
(20.8 \%)\end{array}$ & 3 labels & $\begin{array}{c}\mathrm{N}=6 \\
(6.3 \%)\end{array}$ \\
\hline annoying & $43(44.8 \%)$ & $\begin{array}{l}\text { annoying/ } \\
\text { positive }\end{array}$ & $11(11.4 \%)$ & $\begin{array}{l}\text { pleasant/ } \\
\text { attractive/positive }\end{array}$ & $6(6.3 \%)$ \\
\hline attractive & 0 & $\begin{array}{l}\text { annoying/ } \\
\text { repulsive }\end{array}$ & $7(7.3 \%)$ & & \\
\hline pleasant & $2(2.1 \%)$ & $\begin{array}{l}\text { pleasant/ } \\
\text { positive }\end{array}$ & $2(2.1 \%)$ & & \\
\hline positive & $23(23.9 \%)$ & & & & \\
\hline repulsive & $2(2.1 \%)$ & & & & \\
\hline
\end{tabular}

In question 9 the participants had to decide whether the gender of the narrator (female) was appropriate for the Eggies DRTV short form spot. In Table 11, we can see that $84.4 \%$ of the participants believe that the female narrator was the right choice; $11.4 \%$ believe that the narrator should be a male, whereas $4.2 \%$ claim that the gender was not important.

TABLE 11. Appropriateness of the narrator's gender.

\begin{tabular}{|l|c|c|c|}
\hline & YES & NO & Irrelevant \\
\hline Participants $(\mathrm{N}=96 ; 100 \%)$ & $81(84.4 \%)$ & $11(11.4 \%)$ & $4(4.2 \%)$ \\
\hline Female $(\mathrm{N}=74 ; 77 \%)$ & $60(62.5 \%)$ & $10(10.4 \%)$ & $4(4.2 \%)$ \\
\hline Male $(\mathrm{N}=22 ; 23 \%)$ & $21(21.9 \%)$ & $1(1 \%)$ & 0 \\
\hline
\end{tabular}

\section{Discussion}

The purpose of testing the viewers' response to the Eggies DRTV short form spot was to provide answers to three research questions. Our first research question addressed the issue of credibility and persuasion achieved by means of frequent repetition of identical lexical items, syntactic structures and the advertised product's name. The participants' responses indicated that they found this overload of the same information to be very annoying. Together with the very basic and simple language used in the commercial, these two features of verbal behaviour make the Eggies DRTV short form spot very unattractive, exaggerated and annoying. This finding is in agreement with the theoretical assumptions of other studies in the field of consumer response to commercials, which claim that information overload in the form of frequent repetitions and simple language does not contribute to the persuasiveness of the commercial.

Our second research question dealt with the influence of a highly marked audio-visual delivery on developing the interest and credibility of the commercial. We discovered that the commercial was very or adequately informative and interesting, but not convincing enough to motivate the viewers to buy the product. 
The participants' responses indicate that non-verbal elements, such as music, bright colours, attractive display of food and lively spoken delivery, were the main reasons for enjoying watching the commercial. These results confirm the theoretical assumption that non-verbal elements of the delivery (e.g. music, colour, graphic design) affect emotional response via the peripheral route of persuasion.

Our participants found the commercial funny, interesting, amusing, exciting, happy and entertaining, but also annoying and confusing. These findings confirm the theoretical assumptions that (1) appealing to emotions is a successful way to develop interest in the viewers, and (2) positive emotional strategy guarantees better credibility than positive rational or negative emotional or negative rational strategy of persuasion.

Our last research question addressed the influence of prosody (speaker's voice, pitch, speed and volume) on the viewers' emotional response to the commercial. Although some studies on the influence of the speaker's voice quality on the persuasiveness of a commercial found that fast speech is more convincing and positive, our respondents' answers do not confirm this assumption. In fact, fast delivery was evaluated negatively (e.g. exaggerated) and contributed to the unattractiveness of the commercial. The voice of the speaker was similarly evaluated negatively as annoying. This is another confirmation of the assumption that non-verbal elements have a crucial influence on the emotional response.

According to the findings of a study by Wiener and Chartrand (2014) advertisements targeted at a female audience should use male narrators because women find male voices more convincing. The Eggies DRTV short form spot is more targeted to the female audience and uses a female narrator. Our participants did not find the gender of the narrator important and thus we cannot confirm the assumption by Wiener and Chartrand.

This highly critical response of our participants to the Eggies DRTV short form spot may also be due to increased motivation, interest in the commercial and concentration during the watching. The context of the situation in which the empirical investigation took part was different from the usual context in which DRTV short form spots are transmitted to the TV viewers. Interrupting an interesting TV programme (e.g. a film) with commercial breaks usually has negative influences on viewers, who find such interruptions annoying and tedious. Instead of watching them, they leave the room or change TV channels. Our participants, on the other hand, knew that the viewing of the commercial was part of the teaching course and that the feedback from the empirical investigation would serve as the grounds for further insight into the communicative values of English intonation.

\section{Conclusion}

The paper discussed the effects of verbal and non-verbal features of persuasive communication and their effects on the reception of DRTV short form spots. The study was based on the theoretical framework of the cognitive Elaboration Likelihood Model, according to which persuasive information can be processed via the central or peripheral route depending on the amount of personal interest and motivation of the recipient of information. Appealing to the emotions of disinterested viewers with the purpose of persuading them activates the peripheral route of elaboration.

In order to test these theoretical assumptions we carried out an empirical investigation with a group of highly motivated students of English whose answers indicate that (1) an overload of 
verbal and non-verbal information decreases persuasion; and (2) highly marked prosodic delivery is either exaggerated or funny, while the speaker is perceived as annoying.

We are aware of the limitations of this study, especially because all the participants were nonnative speakers of English. For future research we recommend carrying out a similar study among native speakers of English. A comparison of both results would provide us with more reliable conclusions regarding the effects of verbal and non-verbal features on the reception of DRTV short form spots.

\section{References}

Adler, Rachel F., Francisco Iacobelli, and Yehuda Gutstein. 2015. "Are you Convinced? A Wizard of Oz Study to Test Emotional vs. Rational Persuasive Strategies in Dialogues." Computer in Human Behaviour 57: 75-81. doi:10.1016/j.chb.2015.12.011.

Andrejc, Ksenija. 2005. “Raziskava odnosa ljudi do reklam.” B.A. Thesis, University of Maribor. Accessed April 6, 2016. http://diplome.fov.uni-mb.si/uni/11621Andrejc.pdf.

Areni, Charles S., and John R. Sparks. 2005. "Language Power and Persuasion.” Psychology \& Marketing 22(6):507-25. doi:10.1002/mar.20071.

Averbeck, Joshua M., and Claude Miller. 2014. "Expanding language Expectancy Theory: The Suasory Effects of Lexical Complexity and Syntactic Complexity on Effective Message Design." Communication Studies 65 (1): 72-95. doi:10.1080/10510974.2013.775955.

Chattopadhyay, Amitava, Darren W. Dahl, Robin J. B. Ritchie, and Kimary N. Shahin. 2003. "Hearing Voices: The Impact of Announcer Speech Characteristics on Consumer Response to broadcast Advertising." Journal of Consumer Psychology 13 (3): 198-204. doi:10.1207/S15327663JCP1303_02.

Communication Theory. n.d. "AIDA Model.” Accessed October 15, 2016. http://communicationtheory.org/ aida-model/.

Council of Europe. 2001. Common European Framework of Reference for Languages: Learning, Teaching, Assessment. Cambridge: Cambridge University Press.

Craig, Traci Y., and Kevin L. Blankenship. 2011. "Language and Persuasion: Linguistic Extremity Influences Message Processing and Behavioural Intentions." Journal of Language and Social Psychology 30 (3): 290310. doi:10.1177/0261927X11407167.

Elbert, Sarah P., and Arie Dijkstra. 2014. "An Experimental Test of the Relationship Between Voice Intonation and Persuasion in the Domain of Health." Psychology \& Health 29 (9): 1014-31. doi:10.1080/08870446.2014.903482.

HawthorneDirect. n.d. "Direct Response TV (DRTV) and Infomercial Marketing." Accessed October 15, 2016. http://www.hawthornedirect.com/drtv_101/Short-Form-Spots.htm.

Highstreet TV. 2013. "Eggies.” YouTube Video, 1:17. February 15. https://www.youtube.com/ watch?feature=player_embedded $\& v=1$ gas 0 p $7 \mathrm{ksYk} \#$ !.

Komar, Smiljana. 2015. "Linguistic Features of Persuasive Communication: The Case of DRTV Short Form Spots.” ELOPE 12 (2): 29-52. doi:10.4312/elope.12.2.29-52.

Lakoff, Robin. 1975. Language and Woman's Place. New York: Harper \& Row.

Mai, Li-Wei, and Georgia Schoeller. 2009. "Emotions, Attitudes and Memorability Associated with TV Commercials.” Journal of Targeting, Measurement and Analysis for Marketing 17 (1): 55-63. doi:10.1057/jt.2009.1. 
Nikolaus, Jackob, Thomas Roessing, and Thomas Petersen. 2011. "The Effects of Verbal and Nonverbal Elements in Persuasive Communication: Findings from Two Multi-Method Experiments."

Communications 36: 245-71. doi:10.1515/COMM.2011.012.

O’Barr, William M. 1982. Linguistic Evidence. Language, Power, and Strategy in the Courtroom. New York: Academic Press.

Petty, Richard E., and Pablo Briñol. 2015. "Emotion and Persuasion: Cognitive and Meta-Cognitive Processes Impact Attitudes.” Cognition and Emotion 29 (1): 1-26. doi:10.1080/02699931.2014.967183.

Petty, Richard E., and John Cacioppo. 1986. Communication and Persuasion: Central and Peripheral Routes to Attitude Change. New York: Springer.

Puccinelli, Nancy M., Keith Wilcox, and Dhrub Grewal. 2015. "Consumers' Response to Commercials: When the Energy Level in the Commercial Conflicts with the Media Context." Journal of Marketing 79: 1-18. doi:10.1509/jm.13.0026.

Sparks, John R., and Charles S. Areni. 2002. "The Effects of Sales Presentation Quality and Initial Perceptions on Persuasion: A Multiple Role Perspective." Journal of Business Research 55 (6): 517-28. doi:10.1016/ S0148-2963(00)00173-9.

Wiener, Hillary J. D., and Tanya L. Chartrand. 2014. “The Effect of Voice Quality on Ad Efficacy.” Psychology and Marketing 31 (7): 509-17. doi:10.1002/mar.20712. 


\section{Appendix 1}

\section{Transcription of the Eggies DRTV short form spots.}

\section{Legend:}

XXXX: black and white film

CAPITAL LETTERS: on-screen written text

\section{EGGIES}

Messy shells, broken whites, dirty hands.

Well, not any more.

\section{EGGIES BOILED EGGS WITHOUT THE SHELL!}

Introducing Eggies from New Innovations: the fast, fun, easy way to cook hard or soft boiled eggs without the shell.

JUST CRACK \& POUR

\section{TWIST OPEN}

Just crack and pour in your egg, boil it right on your hob, then twist open for a perfect-looking boiled egg.

\section{COOKS LIKE REAL SHELL!}

Look inside.

\section{EASILY SLIDES OUT!}

Eggies cook your eggs just like a real shell.

And the egg slides right out when you're done.

And here's something really handy.

\section{COOKS FLAT! \\ DECORATE}

Because Eggies cook flat on the bottom, they're easy to decorate.

\section{WITHOUT A SINGLE SHELL!}

Now you can enjoy delicious hard or soft boiled eggs without peeling a single shell.

FAST \& FRESH EGG SANDWICHES SLICED FOR SALADS!

Fast and fresh egg sandwiches or simply slice an egg over a scrumptious salad.

\section{TASTY TREAT KIDS LOVE}

Eggies help make a tasty treat the kids love to eat.

\section{CHOLESTEROL-FREE WHITES}

You can even cook your egg whites for a cholesterol-free alternative.

Look.

Peeling just one egg the regular way can be messy and take time.

$$
\text { QUICK, EASY\& MESS-FREE }
$$

But you can twist open Eggies eggs quick, easy and mess-free.

ADD SEASONING BEFORE BOIL

And because you cook without a shell, you can add seasoning 
ADD INGREDIENTS BEFORE BOIL

and ingredients before you boil.

Watch again.

\section{CRACK COOK TWIST}

Just crack, cook and twist.

With Eggies unique design to enjoy delicious hard or soft boiled eggs just like this.

\section{DISHWASHER SAFE}

And it's dishwasher-safe.

Save time in the kitchen and enjoy hard or soft boiled eggs for breakfast, lunch or dinner the Eggies way.

Got an egg?

Get an Eggies!

\section{Appendix 2}

Pre-viewing questionnaire

Instruction: please circle the appropriate answer.

\begin{tabular}{|l|l|l|}
\hline 1. Gender & \multicolumn{2}{|l|}{ FEMALE } \\
\hline MALE & NO \\
\hline 2. Do you know how to cook a hard-boiled egg? \\
\hline YES & NO \\
\hline 3. Do you find cooking hard-boiled eggs difficult? \\
\hline YES & DIFFICULT & MESSY \\
\hline 4. How do you find peeling a hard-boiled egg? \\
\hline EASY & NO \\
\hline 5. Do you think that cooking and peeling hard-boiled eggs could be made easier? \\
\hline YES \\
\hline $\begin{array}{l}\text { 6. Would you be interested in buying a product which would make cooking and peeling } \\
\text { hard-boiled eggs easier? }\end{array}$ \\
\hline YES & NO & PERHAPS \\
\hline
\end{tabular}




\section{Appendix 3}

Post-viewing questionnaire

\begin{tabular}{|l|l|l|}
\hline \multicolumn{1}{|l}{ 1. How informative was the commercial? } & NOT ENOUGH \\
\hline VERY & JUST ENOUGH & NOUH
\end{tabular}

2. Did the commercial convince you that there was an easier way of cooking and peeling hard-boiled eggs?

YES $\mathrm{NO}$

3. Were you persuaded to buy the product?

\begin{tabular}{|l|l|}
\hline YES & NO \\
\hline
\end{tabular}

4. Provide up to 5 adjectives to describe your emotional reactions to the commercial: 1 .

2.

3 .

4.

5 .

5. Provide up to 5 features which made the commercial appealing:

1 .

2.

3.

4.

5.

6. Provide up to 5 features which made the commercial unattractive:

1 .

2 .

3.

4.

5.

7. How did you find the delivery of the commercial? (You may choose more than one label.) \begin{tabular}{|l|l|l|l|l}
\hline LIVELY & EXCITED & PLEASANT & EXAGGERATED & BORING \\
\hline
\end{tabular}

8. How did you find the voice of the speaker? (You may choose more than one label.)

\begin{tabular}{|l|l|l|l|l}
\hline PLEASANT & ATTRACTIVE & ANNOYING & POSITIVE & REPULSIVE \\
\hline
\end{tabular}

9. Did you find the gender of the speaker appropriate for this commercial?

\begin{tabular}{|l|l}
\hline YES & NO \\
\hline
\end{tabular} 